\title{
Statistical quality control to emission uniformity in micro sprinkler with autonomous
}

\section{photovoltaic pumping}

Controle estatístico de qualidade para uniformidade de emissão em microaspersor com

bombeamento fotovoltaico autônomo

Control estadístico de calidad para uniformidad de emisión en microaspersor con bombeo

fotovoltaico autónomo

Received: 08/26/2021 | Reviewed: 08/31/2021 | Accept: 09/08/2021 | Published: 09/11/2021

\author{
Soni Willian Haupenthal \\ ORCID: https://orcid.org/0000-0003-2598-4133 \\ Universidade Estadual do Oeste do Paraná, Brazil \\ E-mail: soniwillian@ hotmail.com \\ Marcio Antonio Vilas Boas \\ ORCID: https://orcid.org/0000-0003-3444-8164 \\ Universidade Estadual do Oeste do Paraná, Brazil \\ E-mail: marcio.vilasboas@unioeste.br \\ Jair Antonio Cruz Siqueira \\ ORCID: https://orcid.org/0000-0002-8140-444X \\ Universidade Estadual do Oeste do Paraná, Brazil \\ E-mail: jair.siqueira@unioeste.br \\ Luciene Kazue Tokura \\ ORCID: https://orcid.org/0000-0001-9758-0141 \\ Universidade Estadual do Oeste do Paraná, Brasil \\ E-mail: lucienetokura@gmail.com \\ Laís Fernanda Juchem do Nascimento \\ ORCID: https://orcid.org/0000-0002-3790-5896 \\ Universidade Estadual do Oeste do Paraná, Brazil \\ E-mail: laisfjuchem@gmail.com
}

\begin{abstract}
This work aimed to evaluate a microsprinkler irrigation system using photovoltaic energy without energy storage. The influence of photovoltaic pumping on irrigation was evaluated from the Emission Uniformity, Shewhart control charts and Process Capacity. The experiment consisted of two amorphous photovoltaic panels connected in parallel, directly connected to a water pump, where the flow of the pumping system was carried out through a $1 / 2$ " tube (main line), to the irrigation system composed of four microsprinklers. The voltage and current parameters were collected, and the power of the photovoltaic system was calculated, while for the irrigation system the pressures of the four microsprinklers were measured to later calculate the flow rate of the irrigation system. The experiment was conducted at the State University of Western Paraná, UNIOESTE, where 25 days of collection were carried out, in the open, at four different times, from 10:00 am to 11:00 am, from 11:05 am to 12:05 pm, from 2:00 pm to 3:00 pm and from 3:05 pm to 4:05 pm. Power generation presented a low coefficient of variation throughout the day, which resulted in flow and pressure stability, culminating in an Emission Uniformity (UE) value qualified as excellent (93.66\%) according to the ASAE. The values of energy generation, flow, pressure, and emission uniformity presented a Process Capacity (CP) value above 1.33, defining the process as capable and adequate throughout the analyzed period.
\end{abstract}

Keywords: Control chart; Micro irrigation; Process capacity; Solar energy; Sustainability; Uniformity.

\section{Resumo}

Este trabalho teve como objetivo avaliar um sistema de irrigação por microaspersão utilizando energia fotovoltaica sem armazenamento de energia. A influência do bombeamento fotovoltaico na irrigação foi avaliada a partir da Uniformidade de Emissão, gráficos de controle de Shewhart e Capacidade de Processo (Pc). O experimento consistiu em dois painéis fotovoltaicos amorfos conectados em paralelo, diretamente conectados a uma bomba d'água, onde a vazão do sistema de bombeamento foi realizada através de um tubo de $1 / 2$ " (linha principal), até o sistema de irrigação composto por quatro microaspersores. Os parâmetros de tensão e corrente foram coletados e a potência do sistema fotovoltaico foi calculada, já para o sistema de irrigação as pressões dos quatro microaspersores foram medidas para posteriormente calcular a vazão do sistema de irrigação. O experimento foi conduzido na Universidade Estadual do Oeste do Paraná, UNIOESTE, onde foram realizados 25 dias de coleta, a céu aberto, em quatro horários distintos, das $10 \mathrm{~h}$ às $11 \mathrm{~h}$, das $11 \mathrm{~h} 05$ às $12 \mathrm{~h} 05$, das $14 \mathrm{~h} 00$ às $15 \mathrm{~h} 00 \mathrm{e}$ das $15 \mathrm{~h} 05$ às $16 \mathrm{~h} 05$. A geração de energia apresentou baixo 
coeficiente de variação ao longo do dia, o que resultou em estabilidade de vazão e pressão, culminando em um valor de Uniformidade de Emissão (UE) qualificado como excelente $(93,66 \%)$ de acordo com a ASAE. Os valores geração de energia, vazão, pressão e uniformidade de emissão apresentaram valor de Capacidade do Processo (CP) acima de 1,33 definindo o processo como capaz e adequado ao longo do período analisado.

Palavras-chave: Capacidade do processo; Energia solar; Gráfico de controle; Microirrigação; Sustentabilidade; Uniformidade.

\section{Resumen}

Este trabajo tuvo como objetivo evaluar un sistema de riego por microaspersión que utiliza energía fotovoltaica sin almacenamiento de energía. La influencia del bombeo fotovoltaico en el riego se evaluó a partir de la Uniformidad de Emisiones, los gráficos de control de Shewhart y la Capacidad del Proceso. El experimento consistió en dos paneles fotovoltaicos amorfos conectados en paralelo, directamente conectados a una bomba de agua, donde el flujo del sistema de bombeo se realizó a través de un tubo de $1 / 2$ "(línea principal), al sistema de riego compuesto por cuatro microaspersores. Se recogieron los parámetros de voltaje y corriente y se calculó la potencia del sistema fotovoltaico mientras que para el sistema de riego se midieron las presiones de los cuatro microaspersores para luego calcular el caudal del sistema de riego. El experimento se realizó en la Universidad Estatal del Oeste de Paraná, UNIOESTE, donde se realizaron 25 días de recolección, al aire libre, en cuatro horarios diferentes, de 10:00 a.m. a 11:00 a.m., de 11:05 a.m. a 12 p.m. : 05 pm, de 2:00 pm a 3:00 pm y de 3:05 pm a 4:05 pm. La generación de energía presentó un bajo coeficiente de variación a lo largo del día, lo que resultó en estabilidad de flujo y presión, culminando en un valor de Uniformidad de Emisión (UE) calificado como excelente (93,66\%) según la ASAE. Los valores de uniformidad de generación, flujo, presión y emisión de energía presentaron un valor de Capacidad de Proceso (CP) superior a 1,33, definiendo el proceso como capaz y adecuado durante todo el período analizado.

Palabras clave: Capacidad de proceso; Energía solar; Gráficos de control; Micro riego; Sustentabilidad; Uniformidad.

\section{Introduction}

Increases in the need of water resources demands to serve all sectors, whether urban, industrial, or even agricultural, in the irrigation sector, stimulate research aimed at qualitative and rational use (Silva et al. 2013).

Furthermore, population growth requires increasing amounts and promotes competition for water between agriculture and other sectors of the economy (Alves et al. 2015). Thus, technicians and government office to guide the adoption of strategies to minimize water consumption guiding farmers.

Irrigation is the segment that consumes the most water among the large users of water resources. In some regions, consumption by irrigation can exceed $70 \%$ of the total amount used (Dalri et al. 2015).

Therefore, in order to minimize consumption and improve efficiency, the use of a localized irrigation system is essential, since it has greater uniformity in distribution, application efficiency and water productivity (Douh et al. 2013). Thus, localized irrigation applies water with high uniformity, close to the soil surface directly in the plant root zone in small quantities, but with high frequency, keeping the soil close to the root zone, close to the field capacity (Oliveira et al. 2016).

Although works are being developed in photovoltaic irrigation, such as Chandel et al. (2015), Chandel et al. (2017), López-Luque, et al. (2017), Zvala et al. (2020), there is a lack of critical analyzes regarding the quality of uniformity of the irrigation system, since for Reis et al. (2006), evaluating the performance of an irrigation system is a fundamental step before implementing any irrigation management strategy. Therefore, the uniformity coefficients are essential to define the viability of the irrigation system, since high uniformity means less water consumption (Ludwig, 2012).

Thus, the use of a quality irrigation system, emphasizing uniformity with energy for pumping from renewable energy sources, leads to problem-solving in areas without electricity or prolonged droughts (Reca et al. 2016).

Therefore, the autonomous pumping system for irrigation stands out for being applied in small to large scales of energy production, revealing itself as a favorable environmental alternative with reduced initial installation values as it does not require a battery bank. that it is an attractive alternative for irrigation and drinking water supply in urban and rural regions of countries with enormous potential for solar energy where a considerable part of the rural population lives in remote areas 
(Shepovalova et al. 2020).

Since the photovoltaic panel is connected directly to the direct current water pump, the terminal voltage and current are equal to the voltage and current of the photovoltaic matrix, in which the pump speed varies with the level of solar radiation incident on the photovoltaic generator (López-Luque et al. 2017), making the system complex in terms of operation since the pumping will be carried out only in times of solar radiation incidence. However, it is noteworthy that both the plant water requirement and the increase in radiation levels are synchronous (Yahyaoui et al. 2016).

Thus, this work aimed to evaluate the performance of a microsprinkler irrigation system with autonomous photovoltaic pumping, analyzing the generated energy, pressure, and flow of the photovoltaic irrigation system at different times in order to diagnose the interference of radiation variation throughout of the day in the generated energy and consequently in emission uniformity.

\section{Methodology}

The experiment was implemented at the State University of West Paraná - UNIOESTE, Cascavel campus, with Latitude $24^{\circ} 58$ 'South (S), Longitude $53^{\circ} 44^{\prime}$ West (W) and altitude of 753 meters, with average daily solar irradiation for $4.95 \mathrm{kWh} \mathrm{m}^{-2} \mathrm{day}^{-1}$, obtained from the Cresesb website, in the energy potential, solar potential tab and inserting the coordinates of the installation site of the photovoltaic system (Cresesb, 2019) shown in Figure 1, characterizing the region with potential for photovoltaic energy production. The tests were carried out in the experimental area of Unioeste, campus of rattlesnake, where the installation site of the irrigation system has a flat topography composed of grass. The area has trees and undergrowth in the vicinity of the installation of the micro sprinkler irrigation system.

Figure 1. Availability of global horizontal irradiance in Cascavel, Paraná.

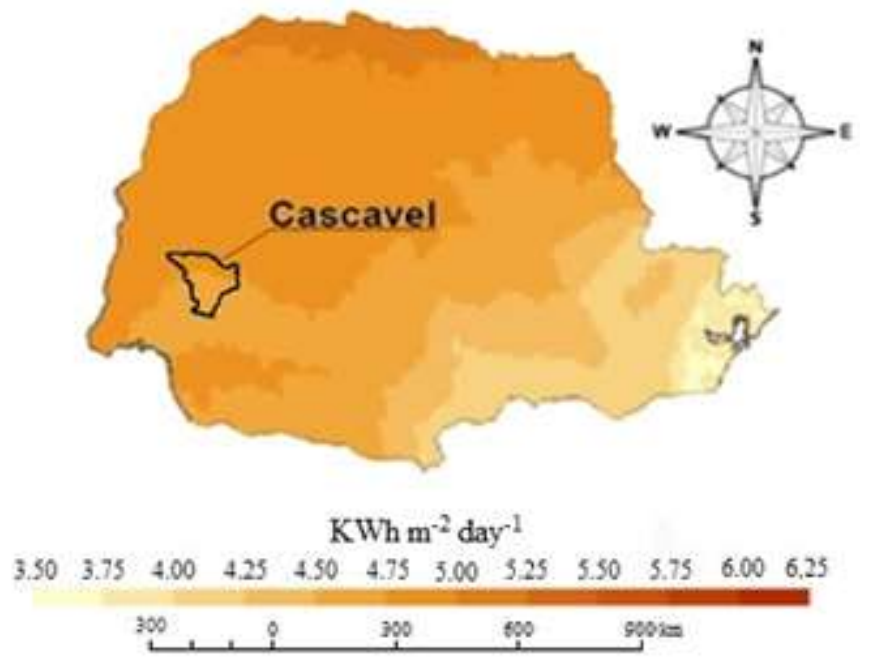

Source: Image adapted from the Pereira et al. (2017).

There were no controlled variables in the experiment since the analysis was made in order to clarify whether the variability of the energy supply system would affect the uniformity of emission throughout the day.

The direct photovoltaic pumping system for micro sprinkler irrigation consists of a photovoltaic matrix, direct current hydraulic pump and micro sprinkler irrigation system.

To carry out the irrigation tests, four different times were used, close to the times defined by Andrade et al. (2017), which establishes the interval from 10:00 am to 2:00 pm, with greater potential for photovoltaic generation. 
In the energy part, two photovoltaic modules of the Solarterra brand of amorphous silicon were used, with a maximum power of $40 \mathrm{Wp}$ each, connected in parallel to raise the system current, directly connected to the water pump.

For the collection of irradiation values, a pyrometer installed close to the panels and on the same inclination was used, connected to a datalogger that collected the data. Current and voltage were also measured and stored by a datalogger, storing 60 values of radiation, current and voltage every hour.

From the collected values of the current and voltage, the generated energy $\left(\mathrm{W} \mathrm{h}^{-1}\right)$ of the photovoltaic system was calculated using Equation 1.

$$
\text { Generated Energy }=\mathrm{V} * \mathrm{C} * \text { Time }
$$

Where V:Voltage (volt), C: Current (ampere), Time: Collection time (hours).

With the power data, the energy values produced in watts hour can be calculated, being equal to the power value, since the test was performed for $1 \mathrm{~h}$.

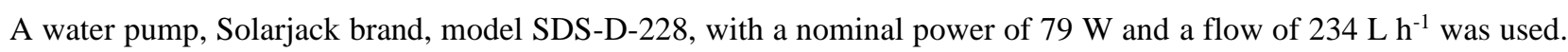
As for the irrigation system, a rotating emitter was used, with a nominal pressure of 10 to 30 Bar, for a flow established from $36 \mathrm{~L} \mathrm{~h}^{-1}$ to $62 \mathrm{~L} \mathrm{~h}^{-1}$.

The pump was installed inside the water tank, working only at times of solar radiation incidence, performing the discharge for the irrigation system formed by four micro sprinklers, framing the system within the characteristics of the photovoltaic irrigation opportunity. The micro sprinklers were spaced 2 × 2 meters, with pressure gauges installed on each emitter in order to establish the pressure at each water outlet point (Figure 2).

Figure 1. Diagram of the irrigation system with photovoltaic panel connected directly to the pumping system.

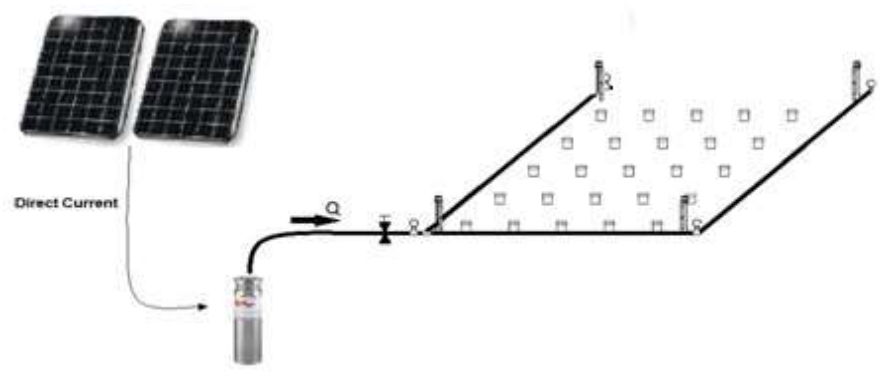

Source: Authors.

To calculate the flow of each emitter in the system (Equation 2), the equation was first defined from the linear regression established with data provided by the micro sprinkler manufacturer, reaching an determination coefficient $\left(\mathrm{R}^{2}\right)$ of 100 .

Micro sprinkler flow rate $\left(\mathrm{L} \mathrm{h}^{-1}\right)=1.3 *$ Pressure $($ Bar $)+23$

The micro sprinklers were numbered according to their position, the first at the beginning of the pipe and the last at the end of the line. Twenty-eight evaluations were carried out for each proposed time, defined as time 1, 10:00 am to 11:00 am; 
time 2, 11:05 am to $12: 05 \mathrm{pm}$; time 3, 2:00 pm to 3:00 pm; time 4, 3:05 pm to 4:05 pm. Also seeking to define the feasibility of expanding the schedule defined by Andrade et al. (2017), increasing the hours within the photovoltaic irrigation opportunity.

Thus, the emission uniformity (EU) values were calculated for each of the 25 days of collection since the proposal is defined by analyzing the interference of the irradiation variation in the photovoltaic panels in the emission of the micro sprinklers along the day.

In addition to the emission uniformity (EU) for each of these times, the standard deviation, coefficient of variation, variance, maximum, minimum, and normality were calculated using the Kolmogorov method.

Coefficient of Variation (Equation 3), according to the ASAE (2003), is a measure of the flow variability of a random sample of a given manufacturing model and emitter size, and it is produced by the manufacturer and before any operation or aging in the field.

$$
\begin{gathered}
C_{\mathrm{V}}=\frac{s}{x} \\
s=\sqrt{\left|\frac{\sum_{1}^{n}\left(x_{1}-x^{2}\right)^{2}}{n-1}\right|}
\end{gathered}
$$

Where $\bar{x}$ : The mean discharge of emitter in the sample, s: The standard deviation of discharge of emitter in the sample, xi: the discharge of the emitter, n: the number of the emitter in the sample.

The classification of the coefficient of variation $(\mathrm{Cv})$ defined by the American Society of Agricultural and Biological Enginners $(3,2008)$ in the design and installation of the micro irrigation system is shown in Table 1.

Table 1. Recommended classification of manufacturer's coefficient of variation $(\mathrm{Cv})$.

\begin{tabular}{ccc}
\hline Emitter type & Cv Range & Classification \\
\hline & $<0.05$ & Excellent \\
& 005 to 0.07 & Average \\
Point- source & 0.07 to 0.11 & Marginal \\
& 0.11 to 0.15 & Poor \\
& $>0,15$ & Unacceptable \\
Line - source & $<0.10$ & Good \\
& 0.10 to 0.20 & Average \\
& $>0.20$ & Marginal to unacceptable \\
\hline
\end{tabular}

Source: American Society of Agricultural Engineers - ASAE (2003)

Emission uniformity (EU), established by ASAE (2003), is the specifically equation for micro sprinkler irrigation systems since it estimates uniformity in terms of the coefficient of variation and pressure in the emitter.

$$
E U=100\left[1-\frac{1.27 * C V}{\sqrt{n}}\right] * \frac{q_{n}}{q_{a}}
$$


Where EU: Emission Uniformity (\%), n: for a point-source emitter on a perennial crop the number of emitter per plant, for a line-source emitter on an annual or perennial row crop, either the lateral rooting diameter of the plants divided by the same unit length of lateral line used to calculate $\mathrm{CV}$ or 1, which is greater, CV: the manufacturer's coefficient of variation for point or line-source emitters, qm: the minimum flow rate of the emitter for the minimum pressure in the subunit $\left(\mathrm{L} \mathrm{h}^{-1}\right)$, qa: the average flow rate of the emitter for the subunit $\left(\mathrm{L} \mathrm{h}^{-1}\right)$.

The interpretation of the calculated values can be referenced from Table 2, highlighting the importance of defining characteristics such as spacing, topography, slope and type of emitter that were used in the design.

Table 2. Recommended ranges of design emission uniformity (EU).

\begin{tabular}{ccccc}
\hline Emitter type & Spacing (m) & Topography (\%) & Slope (\%) & EU range (\%) \\
\hline Point source on perennial crops & $>4$ & $\begin{array}{c}\text { Uniform } \\
\text { steep or undulating }\end{array}$ & $>2$ & 90 to 95 \\
$\begin{array}{c}\text { Point source on perennial or } \\
\text { semi-permanent crops }\end{array}$ & $<4$ & Uniform & 85 to 90 \\
$\begin{array}{c}\text { Line source on annual or } \\
\text { perennial crops }\end{array}$ & All & Steep or undulating & $>2$ & 85 to 90 \\
& & Uniform & 80 to 90 \\
& steep or undulating & $>2$ & 80 to 90 \\
\end{tabular}

Source: American Society of Agricultural Engineers - ASAE (2003).

Shewhart control charts were generated for the individual means in order to verify whether the results were under statistical control. It should be noted that when the values are plotted within the limits, both lower and upper, the process is considered under control and no action is necessary; on the other hand, if the point is outside the limits it is interpreted as evidence that the process is out of control, therefore requiring investigation and corrective action (Montgomery, 2009).

The upper control limit (UCL) and the lower control line (LCL) values were calculated from Equation 6 and 7.

$$
\begin{aligned}
& U C L=\overline{\bar{X}}+3 \frac{\bar{A}}{d_{2}} \\
& L C L=\overline{\bar{X}}-3 \frac{\bar{E}}{d_{2}}
\end{aligned}
$$

Where $\overline{\bar{X}}$ : Average of the averages, $R$ : Average data amplitudes, $\mathrm{d}_{2}: 1.128$ for $\mathrm{n}=2$, considering individual averages, according to the table described by Montgomery (2009).

Finally, the value of the process capacity index was calculated, since they are used to determine if a process is capable of meeting a tolerance range, and they must be analyzed later to test for approximation to normal distribution and with process under statistical control. For this purpose, Equation 8 was used.

$$
C p=\frac{U S L-L S L}{6 \sigma}
$$

Where USL: Upper specification limit, LSL: Lower specification limit, $\sigma$ : Standard deviation estimator. 
According to Montgomery (2009) the process is capable if the specification limits previously established by standards are adequately greater than the control range.

Still according to the author, the capacity of the process is classified considering that, if the value of $\mathrm{Cp}>1.33$, the process is capable or adequate, according to the specifications, however if the value is $1<\mathrm{Cp}<1.33$, the process is acceptable and if $\mathrm{Cp}<1$, the process is inefficient or inadequate.

Through Minitab (2012) the process capacity was calculated using bilateral limits according to the ASAE (2003) classification for emission uniformity and the nominal values for the pressure, flow, and power of the photovoltaic panel.

The values of coefficient of variation, standard deviation, variance, maximum, minimum, and p-value of the analyzed parameters were also calculated to define the descriptive statistics. Was also established the regression between emission uniformity, coefficient of variation of emission uniformity, power of the panel and average flow of the micro sprinklers seeking to establish correlations between parameters.

\section{Results and Discussion}

\subsection{Descriptive data statistics}

Table 3 presents the descriptive statistics for the variables of emission uniformity, power of the photovoltaic panel, system pressure, wind speed and flow rate of the sprinklers, in which the values of mean, coefficient of variation, standard deviation, variance, maximum and minimum, and p-value are counted.

Table 3. Descriptive statistics of the collected data.

\begin{tabular}{cccccc}
\hline Analyze & EU (\%) & Generated energy (Wh) & Pressure (Bar) & Wind $\left(\mathbf{m ~ s}^{\mathbf{- 1}}\right)$ & Flow rate $\left(\mathbf{L ~ h}^{\mathbf{- 1}}\right)$ \\
\hline Mean & 93.660 & 59.800 & 22.007 & 0.9275 & 43.831 \\
Coeff. of Variation & 0.023 & 0.059 & 0.054 & 0.265 & 0.053 \\
Standard deviation & 2.198 & 3.582 & 1.186 & 0.243 & 2.34 \\
Variance & 4.830 & 12.828 & 1.407 & 0.059 & 14.828 \\
Maximum & 96.051 & 67.936 & 23.919 & 1.269 & 51.822 \\
Minimum & 89.516 & 51.092 & 20 & 0.392 & 42.471 \\
p-value & 0.07 & 0.083 & 0.15 & $0.044^{*}$ & 0.15 \\
\hline
\end{tabular}

*Kolmogorov normality test, at 5\% significance. Source: Authors.

As shown in the table, the EU value (93.66\%) reached a value in agreement with the ASAE (2003), as well as a low coefficient of variation value (2.3\%).

The average energy generated from the photovoltaic panel was below the ideal operating values of the pump (79 Wh), reducing the nominal flow from $234 \mathrm{~L} \mathrm{~h}^{-1}$ to $174.22 \mathrm{~L} \mathrm{~h}^{-1}$, that is, with a decrease of $25.316 \%$ of power required by the pump, there was a reduction of $25.547 \%$ in the flow to the irrigation system. Emphasizing that despite variations in collection times that imply considerable amplitude in solar radiation, the standard deviation of panel power (3.582) remained low.

Therefore, despite the energy supply values below the rated power of the water pump, the stabilization of energy over the collection periods resulted in low coefficient of variation values for the pressure, flow and emission uniformity parameters, resulting in in high emission uniformity. It is noteworthy that the flow and pressure parameters remained within the nominal values. 
For the climatic factor of the wind, it is noted that the average speed did not exceed $1 \mathrm{~m} \mathrm{~s}^{-1}$, and even its maximum value did not approach what Zhang et al. (2013) define as necessary to interfere in the micro sprinkler irrigation system (1.8 $2.0 \mathrm{~m} \mathrm{~s}^{-1}$ ) the high $\mathrm{CV}$ value (24.3\%), which is consistent with the study of sprinkler irrigation by Frigo et al. (2013) in which they obtained $\mathrm{CV}$ values that ranged from 5.35 to $57.79 \%$. This variable was the only one that did not show normality at $5 \%$ significance. This fact is justified because there are high variations in agricultural studies in the field (Pimentel Gomes, 2000), regarding the wind speed parameter, supplanting the question of data normality.

\subsection{Equation fit}

To verify the association between the emission uniformity, coefficient of variation, flow and power of the photovoltaic panel, the equations were obtained from the data means. For that, the determination coefficient $\left(\mathrm{R}^{2}\right)$ was adopted for the expressions with the best fit, presented in Table 4.

Table 4. Regression between emission uniformity, coefficient of variation of emission uniformity, power of the panel and average flow of the micro sprinklers.

\begin{tabular}{lc}
\hline Expression & $\mathbf{R}^{2}$ \\
\hline 1) $\mathrm{UE}=106,1 * \mathrm{CV} 2-68,40 * \mathrm{CV}+100,1$ & 99.40 \\
2) $\mathrm{UE}=-0,079 *$ Flow rate $2+7,783 *$ Flow rate $-94,46$ & 79.70 \\
3) Flow rate $=-2,856 * \mathrm{CV}+48,71$ & 76.60 \\
4) Flow rate $=0,774 *$ Generated energy $2-1,970$ & 65.40 \\
5) $\mathrm{UE}=-0,044 *$ Generated energy $2+5,831 *$ Generated energy $2-96,99$ & 62.40 \\
\hline
\end{tabular}

Source: Authors.

The results show the existence of a strong polynomial correlation in expression 1, relating emission uniformity and coefficient of variation.

In expression 2, relating EU to the flow. And a linear correlation in expression 3, relating the flow of microsprinklers and the coefficient of variation of emission uniformity.

From these equations, it can be defined that, as the flow increases, the EU increases, and the CV decreases.

Expressions 4 and 5 reached the level of 65.40 and $62.40 \%$ of $\mathrm{R}^{2}$ showing a satisfactory correlation between the studied parameters, where expression 4 relates the flow of microsprinklers with the energy generated from the photovoltaic panel. Expression 5 relates the energy generated with the EU.

Through the expressions, it can be seen that for the increase in energy generated by the photovoltaic panel there is an increase in flow and, consequently, an increase in the EU values.

A similar response was obtained in a research using microsprinkler irrigation and a photovoltaic panel, where Andrade et al. (2017) where the authors obtained greater precipitation when the values of energy supplied to the pumping system increased.

Contextualizing the expressions and their correlation coefficients, it can be assertively affirmed that for the highest power values of the photovoltaic panel, greater flow rates occur, and therefore a lower coefficient of variation, culminating in greater Emission Uniformity. 


\subsection{Shewhart control chart}

To identify whether the process was under statistical control, Shewhart control charts were proposed for individual EU measurements in order to identify the variation in uniformity during the 25 tests. The acceptable limit of $90 \%$ was also indicated in the chart, according to the classification proposed by ASAE (2003). A control chart was also proposed in relation to flow, power and pressure, in order to justify the variability that occurred in the EU chart.

Figure 3 shows the Shewhart control charts for EU, generated energy, pressure, and flow, of the 25 tests.

Figure 3. Shewhart control chart for the emission uniformity (EU), generated energy, pressure, and flow rate variables.
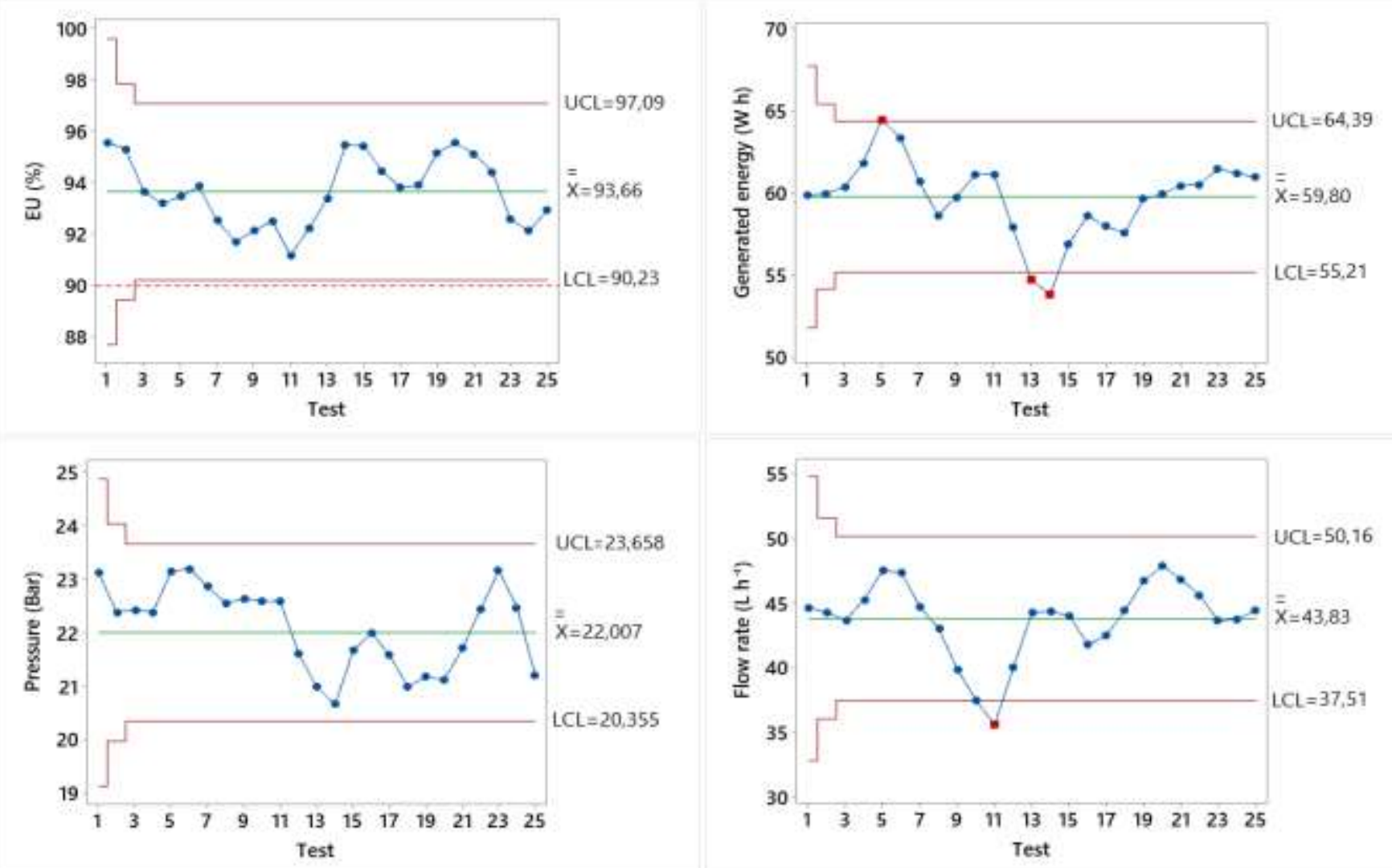

Source: Authors.

In the chart referring to the EU there were no points outside the upper and lower limit, but it was considered out of statistical control according to Frigo (2014) for showing a positive trend with nine points above the average line. It should be noted that despite not being under statistical control, the chart stands out positively because all points are above the value considered by ASAE (2003), since the higher the emission uniformity, the better the irrigation system.

Points 1, 2, 14, 15 and 20 presented the highest EU values, and for the same tests the flow was above the average. On the other hand, the lowest EU value was found at point $11(91.19 \%)$, a test that also presented a lower flow value, being even below the lower specification limit.

As for the power chart, there are points above and below the limits, characterizing the variable as out of statistical quality control, a characteristic that is also found for the pressure chart, since it showed 10 points below the average line (Ribeiro \& Caten, 2012). 
Therefore, because it is a research conducted outdoors with the interference of weathering and the energy supply is carried out directly to the pump, there were great variations in the process, which are more efficiently verified by the Shewhart charts.

The use of Shewhart control charts was more efficient in evaluating the uniformity, for the tests performed in a field sprinkler irrigation system, since there were large variations caused by the influence of the wind (Frigo, 2014).

Therefore, all variables showed a lack of statistical control both due to positive or negative trends, as well as to points outside the limits, where it is assumed that a plausible answer to the wide variability is the change in radiation throughout the tests, which interfere in the tension and current, changing the flow and pressure values of the irrigation system, affecting them both positively and negatively.

It is also worth highlighting the visual similarity between the EU - Flow and Power - Pressure charts, confirming the values of both bivariate and multivariate regression calculations previously showed.

\subsection{Process Capacity Index}

Table 5 shows the calculated values of the process capacity $(\mathrm{Pc})$, for the 25 tests indicating that for EU the lower and upper specification limit was determined according to the ASAE (2003), for the power the limits were defined according to the curve characteristic of the pump to meet the flow parameters of the micro sprinklers (79 to $55 \mathrm{Wh}$ ), while for pressure (10 to $30 \mathrm{Bar}$ ) and flow (62 to $36 \mathrm{~L} \mathrm{~h}^{-1}$ ) the limits were determined according to the nominal values.

Table 5. Calculated values of process capacity index (Pc), for the 25 tests for the EU, power, pressure, and flow variables.

\begin{tabular}{lcc}
\hline Variable & Mean & Pc \\
\hline EU $(\%)$ & 93.660 & 1.457 \\
Generated energy $(\mathrm{Wh})$ & 59.400 & 1.523 \\
Pressure (Bar) & 22.013 & 5.347 \\
Flow rate $\left(\mathrm{L} \mathrm{h}^{-1}\right)$ & 44.201 & 1.949 \\
\hline
\end{tabular}

Source: Authors.

From the calculated results, it can be defined that all variables under analysis have the process capacity index (Pc) capable of reaching the nominal specification value according to the one proposed by Montgomery (2009), classifying the system as capable or appropriate.

Similar results regarding the feasibility of using quality control were found by Justi et al. (2010), who stated, after studying the process capacity for assessing sprinkler irrigation, the increase in the process capacity index proportional to the increase in distribution uniformity, reaching a Pc of 3.00 for uniformity greater than $80 \%$.

Tamagi et al. (2016), when analyzing the uniformity of irrigation water distribution by compensating and noncompensating sprinklers at different heights, found Pc values for the CUC, DUC and EU variables that varied from 1.43 to 4.25 , that is, capable according to the classification of Montgomery (2009). 


\section{Conclusion}

The classification of excellence in the analysis of the Coefficient of Variation was defined as a result of the variables of energy, pressure, and flow, which remained within the nominal specifications and presented low values of coefficient of variation.

The Regressions pointed out that the higher the irradiation value, the better the emission uniformity.

The preparation of the control charts allowed the recognize the existence of some non-random patterns to identify trends and concisely analyze the variables presented in this study, defining this presence or passage of clouds are characteristics that interfere in the uniformity of the irrigation process.

Finally, the process capacity index values were presented as defining, since the variables analyzed presented values higher than those stipulated in the literature, able to maintain adequate levels of uniformity of emission throughout the irrigation period.

\section{Acknowledgments}

The authors thank the State University of Western Paraná, Cascavel campus, for their support in the study.

\section{References}

Alves, E. S., Araujo, L. M., Alves, J. S. D., Santos, J. E. O., \& Zimback, C. R. L. (2015). Geoestatistica aplicada a uniformidade de aplicação de água em sistemas de irrigação por gotejamento usado e novo. Revista Brasileira de Agricultura Irrigada, 9(3), 127-135. https://doi.org/10.7127/rbai.v9n300298.

Andrade, M. G., Vilas Boas, M. A., Siqueira, J. A. C., Dieter, J., Sato, M., Hermes, E., Mercante, E., \& Tokura, L. K. (2017). Statistical quality control for the evaluation of the uniformity of microsprinkler irrigation with photovoltaic solar energy. Renewable and Sustainable Energy, 78, 743-753. 10.1016/j.rser.2017.05.012

American Society of Agricultural Engineers. ASAE. (2003). Field evaluation of micro irrigation systems. EP458, St. Joseph, 760-765

Campana, P. E., \& H. Li, J. (2013). YanDynamic modelling of a PV pumping system with special consideration on water demand. Appl. Energy, 112, 635645. https://doi.org/10.1016/j.apenergy.2012.12.073.

Chandel, S. S., Naik, M. N., \& Chandel, R. (2017). Review of performance studies of direct coupled photovoltaic water pumping systems and case study. Renewable and Sustainable Energy Reviews, 76, 163 - 175. https://doi.org/10.1016/j.rser.2017.03.019

Chandel, S. S., Naik, M. N., \& Chandel, R. (2015). Review of solar photovoltaic water pumping system technology for irrigation and community drinking water supplies. Renewable and Sustainable Energy Reviews, 49, 1084 - 1099. https://doi.org/10.1016/j.rser.2015.04.083

Centro de Referência para Energia Solar e Eólica Sérgio de Sálvio Brito. CRESESB. (2019). Available in: <http:// http://www.cresesb.cepel.br/index.php?section=sundata > [accessed September/2019].

Dalri, A. B., Garcia, C. J. B., Zanini, J. R., Faria, R. T., \& Palaretti, L. F. (2015). Caracterização técnica e desempenho hidráulico de quatro gotejadores autocompensantes utilizados no Brasil. Revista Ciência Rural, 45, 1439-1444. http://dx.doi.org/10.1590/0103-8478cr20140860.

Douh, B., Boujelben, A., Khila, S., \& Bel HahMguidiche, A. (2013). Effect of subsurface drip irrigation system depth on soil water content distribution at different depths and different times after irrigation. Larhyss Journal, 13, 7-16. https://pdfs.semanticscholar.o rg/de3f/97555b4c3501792bb24710a8e95e779e64f9.pdf.

Frigo J. P.Controle estatístico da qualidade na irrigação por aspersão. (2014). Thesis Doctorate. State University of Western Paraná, Cascavel.

Frigo, J. P., Vilas Boas, M. A., Frigo, E. P., Hermes, E., \& Tessaro, E. (2013). Irrigação diurna e noturna em um sistema de aspersão convencional em Palotina - PR. Irriga, 18(2), 318-327.

Justi, A. L., Vilas Boas, M. A., \& Sampaio, S. C. (2010). Índice de capacidade do processo na avaliação da irrigação por aspersão. Engenharia Agrícola, 30 (2), 264-270. 10.1590/S0100-69162010000200008

López-Luque, R., Martínez, J., Reca, J., \& Ruiz, R. (2017). Análisis de viabilidad y gestión del riego en invernaderos mediterráneos con energía solar fotovoltaica. Ribagua, 4, 1-10. https://doi.org/10.1080/23863781.2017.1332806.

Minitab. (2012). User'Guide Release 16 for Windows. State College, Pennsylvania. United States.

Montgomery, D. C. (2009). Introdução ao controle estatístico da qualidade. Tradução Ana Maria Lima de Farias, Vera Regina Lima de Farias e Flores; Revisão técnica Luiz da Costa Laurencel. (4a ed.), LTC. 
Research, Society and Development, v. 10, n. 11, e581101119867, 2021

(CC BY 4.0) | ISSN 2525-3409 | DOI: http://dx.doi.org/10.33448/rsd-v10i11.19867

Oliveira, E. V., Arraes, F. D. D., Torres, W. L. V., Souza, S. A., \& Vieira, W. L. (2016). Desempenho de um sistema de irrigação por microaspersão e estimativa da demanda hídrica para diferentes fruteiras no município de Iguatu - CE. Revista Conexoes - Ciencias e tecnologia, 10(2), 40-46.

Pereira, E. B., Martins, F. R., Gonçalvez, A. R., Costa, R. S., Lima, F. J. L., Ruther, R., Abreu S. L., Tiepolo, G. M., Pereira, S. V., \& Souza, J. G. (2017). Atlas Brasileiro de Energia Solar. (2a ed.), INPE.

Pimentel Gomes, F. (2000). Curso de estatística experimental. (14a ed.), Degaspari.

Pinho, J. T., \& Galdino, M. A. (2014). Manual de engenharia para sistemas fotovoltaicos. <http://www.cresesb.cepel.br/pu blicacoes/download/Manual_de_Engenharia_FV_2014.pdf>

Reca, J., Torrente, C., López-Luque, R., \& Martínez, J. (2016). Feasibility analysis of stand alone direct pumping photovoltaic system for irrigation in Mediterranean greenhouses. Renew Energy, 85,1143-1154. https://doi.org/10.1016/j.renene.2015.07.056

Reis, M. M., Paladini, E. P., Khator, S., \& Sommer, W. A. (2006). Artificial intelligence approach to support statistical quality control teaching. Computers \& Education, 47, 448-464.

Shepovalova, O. V., Belenov, A. T., \& Chirkov, S. V. (2020). Review of photovoltaic water pumping system research. Energy Reports, 6, 306 - 324. https://doi.org/10.1016/j.egyr.2020.08.053

Silva, V. P. R., Tavares, A. L., \& Sousa, I. F. (2013). Evapotranspiração e coeficientes de cultivo simples e dual do coentro. Revista Horticultura Brasileira, 31, 255-259. http://dx.doi.org/10.1590/S0102-05362013000200013

Tamagi, J. T., Uribe-Opazo, M. A., Johann, J. A., \& Vilas Boas, M. A. (2016). Uniformidade de distribuição de água de irrigação por aspersores compensantes e não compensantes em diferentes alturas. Irriga, 21(4), $631-647$.

Yahyaoui, I., Yahyaoui, A., Chaabene, M., \& Tadeo, F. (2016). Energy management for a stand-alone photovoltaic-wind system suitable for rural electrification. Sustain, Cities Soc., 25, 90-101. http,//dx.doi.org/10.1016/j.scs.2015.12.002

Zavala V., López-Luque, R., Reca, J., Martínez, J., Lao, M. T. (2020). Optimal management of a multisector standalone direct pumping photovoltaic irrigation system. Applied Energy, 260, 114261. https://doi.org/10.1016/j.apenergy.2019.114261

Zhang J., Liu, J., Campana, P. E., Zhang, R., Yan, J., \& Gao, X. (2014). Model of evapotranspiration and groundwater level based on photovoltaic water pumping system. Appl. Energy, 136, 1132-1137. http://dx.doi.org/10.1016/j.apenergy.2014.05.045

Zhang, L., Merkley, G. P., \& Pinthong, K. (2013). Assessing whole-filed sprinkle irrigation application unifomity. Irrigation Science, 31, 87-105. https://doi.org/10.1007/s00271-011-0294-0 